\title{
Pre-Concentration and Determination of Trace Uranium (VI) in Environments using Ion-imprinted Chitosan Resin via Solid Phase Extraction
}

\author{
Yunhai Liu, *,a,b Xiaohong Cao, ${ }^{b}$ Zhanggao Le, ${ }^{a, b}$ Mingbiao Luo, ${ }^{a, b}$ Wenyuan X ${ }^{b}$ and \\ Guolin Huang ${ }^{b}$
}

\author{
${ }^{a}$ Key Laboratory of Nuclear Resources and Environment (ECIT), Ministry of Education, \\ Nanchang 330013, P. R. China \\ ${ }^{b}$ Department of Applied Chemistry, East China Institute of Technology, 56 Xuefu Road, \\ Fuzhou 344000, P. R. China
}

\begin{abstract}
Foram preparadas resinas quitosana de ligação cruzada com impressão molecular de uranil e sem impressão, possuindo grupamentos quinolin-8-ol. Em todos os casos um efeito de impressão significativo foi observado na comparação do percentual de extração de urânio (VI). A resina com impressão molecular foi usada para pré-concentração extrativa de urânio (VI) em fase sólida antes de determinação espectrofotométrica. Variáveis experimentais que influenciam a extração quantitativa de urânio (VI) foram otimizadas em método estático e em extração com coluna. A capacidade de retenção de urânio (VI) foi de $218 \mathrm{mg}$ por g de resina, que é maior que a resina sem impressão molecular correspondente ou outra fase sólida adsorvente que possua grupamento quinolin-8-ol. $\mathrm{O}$ intervalo de $\mathrm{pH}$ ótimo encontrado foi 4,5-7,0. $\mathrm{O}$ urânio adsorvido foi fácil e quantitativamente eluido com $\mathrm{HCl} 1 \mathrm{~mol} \mathrm{~L}^{-1}\left(10 \mathrm{~mL}\right.$ ) sob uma vazão de $2 \mathrm{~mL} \mathrm{~min}{ }^{-1}$. Estudos de interferentes mostraram uma alta tolerância para diversos íons e espécies eletrolíticas. O limite de detecção foi de $2 \mu \mathrm{L} \mathrm{L}^{-1}$ e o intervalo de concentração linear de 5-100 $\mu \mathrm{g} \mathrm{L}^{-1}$. A exatidão do método foi testada com material padrão de referência de rocha de urânio. Além disso, o método foi aplicado para a determinação de urânio em amostras de solo contaminado e sedimento.
\end{abstract}

The uranyl-ion-imprinted and non-imprinted cross-linked chitosan resins possessing quinoline8-ol moiety have been prepared. In all the cases, a significant imprinting effect was noticed on comparing percent extraction of uranium (VI). The resulting ion-imprinted resin was used for solid phase extractive preconcentration of uranium (VI) prior to its determination by spectrophotometry. Experimental variables that influence the quantitative extraction of uranium (VI) were optimized by both static and column methods. The retention capacity found for uranium (VI) was $218 \mathrm{mg} \mathrm{g}^{-1}$ of resin which is higher than the corresponding non-imprinted resins and other solid phase extraction sorbents possessing quinoline-8-ol moiety. The optimum $\mathrm{pH}$ range was 4.5-7.0. Uranium adsorbed was easily and quantitatively eluted with $1 \mathrm{~mol} \mathrm{~L}^{-1} \mathrm{HCl}(10 \mathrm{~mL})$ at a flow rate of $2 \mathrm{~mL} \mathrm{~min}^{-1}$. Interference studies showed a high tolerance of diverse ions and electrolyte species. The limit of detection was $2 \mu \mathrm{g} \mathrm{L} \mathrm{L}^{-1}$ and the dynamic linear range was 5-100 $\mu \mathrm{g} \mathrm{L}^{-1}$. The accuracy of the developed method was tested with one uranium ore standard reference material. Furthermore, the proposed method was successfully applied for the determination of uranium in contaminated soil and sediment samples.

Keywords: chitosan, quinoline-8-ol, ion-imprinted resin, solid phase extraction, uranium (VI)

\section{Introduction}

Uranium finds extensive applications as nuclear fuel in power plants and is widely distributed in the environment and occurs at low levels in water, soil, rocks,

*e-mail: walton_liu@163.com plants and animals. Similar to lead, uranium and its compounds are highly toxic and cause acute cytotoxicity and phenotypic effects on rat and human osteoblasts, the cells responsible for bone formation. ${ }^{1}$ According to World Health Organization guidelines and the US Environmental Protection Agency, the maximum concentration level of uranium in drinking waters has been regulated to be below 
15 and $30 \mathrm{ng} \mathrm{mL}^{-1}$, respectively. ${ }^{2}$ Uranium concentrations in natural environment are usually very low. Thus, the pre-concentration technique is prerequisite for the accurate determination of uranium at low concentration level. Many methods have been developed for an effective separation and pre-concentration of uranium. Procedures based on ion exchanges, ${ }^{3}$ solvent extractions, ${ }^{4}$ and solid phase extractions (SPEs) ${ }^{5}$ are among them. Recently, SPE has come to the forefront due to its several merits over other pre-concentration techniques: high enrichment factors; low intrinsic costs; low solvent consumption; shorter processing times; simpler processing procedures; ease of automation and most significantly environmentally friendlier.

Commercially available solid phase sorbents with metal-retaining functional group, such as iminodiacetate and dipentylpentylphosphonate have been developed for the collection/pre-concentration of uranium. ${ }^{6-8}$ Moreover, some researchers synthesized several kinds of sorbents containing such functional groups, as amidoxime, salicylic acid, dihydroxyazobenzene and maleic acid and used for the pre-concentration of uranium. ${ }^{9}$ However, these sorbents were found to have some serious problems such as a low adsorbing ability and a large amount of acidic waste water. Chitosan, obtained through partial chitin deacetylation, is one of excellent base substances for novel sorbents synthesis, provided by the presence of the numerous functional amino groups for chemical modifications. Compared with the synthetic polymer materials, such as poly(styrenedivinylbenzene), polyethylene and polyurethane, the chitosan has several advantages: ${ }^{10}(i)$ high hydrophilicity due to hydroxyl groups of glucose units; (ii) presence of a large number of primary amino and hydroxyl groups; (iii) flexible structure of the polymer chain. Inoue and $\mathrm{Baba}^{11}$ synthesized various types of chelating resins with cross-linked chitosan, which contain such group as oxine, pyridine, thiophene, thioether, carboxylate, iminodiacetate and EDTA. Recently, Oshita and co-workers ${ }^{12}$ synthesized several novel chitosan resins derivatized with serine moiety, phenylarsonic acid moiety, ${ }^{13}$ iminodi(methylphosphonic acid) moiety ${ }^{14}$ and 3,4-dihydroxybenzoic acid ${ }^{15}$ for collection/pre-concentration of uranium, which offered excellent uranium retention capacities of 49.4, 83, 117.5 and $330 \mathrm{mg} \mathrm{g}^{-1}$ resin, respectively.

Quinoline-8-ol moiety has been immobilized in amberlite XAD $-4^{16}$ and anchored in chloromethylated polymeric resin beads, ${ }^{17}$ which offered uranium retention capacities of 2.74 and $120.3 \mathrm{mg} \mathrm{g}^{-1}$, respectively. Inoue and co-workers have prepared $\mathrm{Ga}$ templated quinoline8-ol chitosan and investigated its adsorption of Mo(IV), V(IV), In(III), Al(III), Zn(II), Fe(II), Cd(II), and Ga(III). ${ }^{18}$ However, there is no reports on the chitosan resin possessing quinoline-8-ol moiety, which is used as solid phase sorbents for the pre-concentration of uranium.

In this work, to improve the pre-concentration of trace uranium in environmental samples before the spectrophotometric measurement, an ion-imprinted technology ${ }^{19}$ was employed. We have synthesized the uranyl-ion-imprinted and non-imprinted cross-linked chitosan resins possessing quinoline-8-ol moiety. The ionimprinted chitosan resin shows higher retention capacities of uranium than non-ion-imprinted chitosan resin and other polymeric resins modified with quinoline-8-ol. The pre-concentration of uranium (VI) using the ion-imprinted cross-linked chitosan resin via solid phase extraction was investigated. The validity of the developed preconcentration method was tested by analyzing one uranium ore standard reference material for uranium. Further, the possible use of the proposed method for the determination of uranium in soil and sediment samples was investigated.
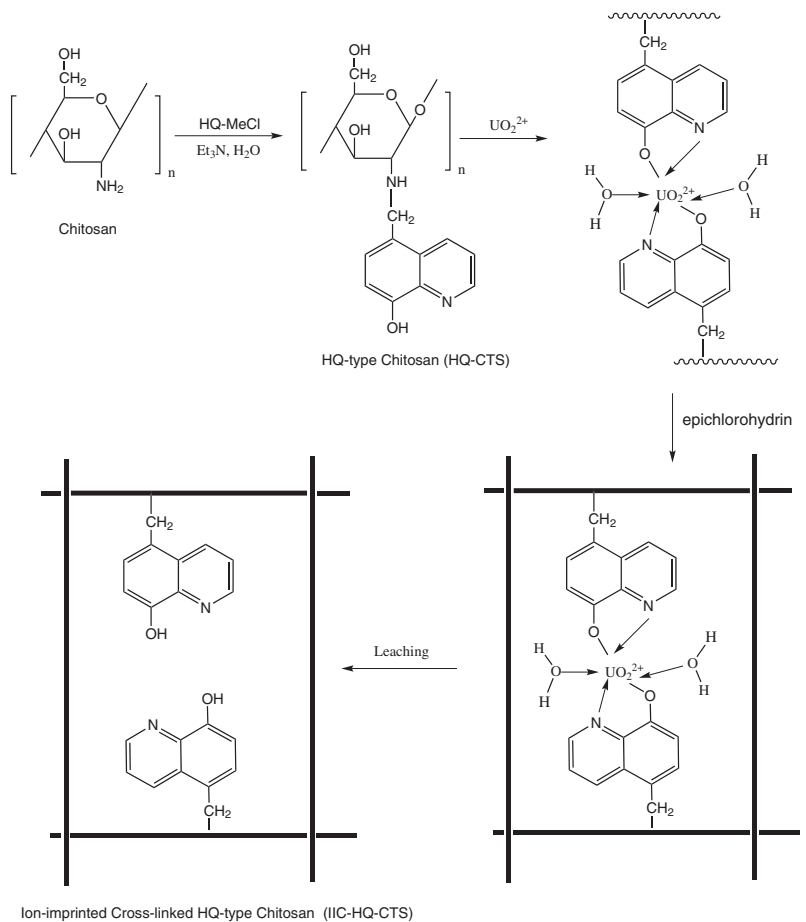

Figure 1. Scheme for preparation of uranyl IIC-HQ-CTS resin.

\section{Experimental}

\section{Reagents and chemicals}

Chitosan was supplied by Zhejiang Yuhuan Chemical Engineer Co., the deacetylated degree of which was about 90\%. 5-Chloromethyl-8-quinolinol was obtained from Aldrich. All other reagents and solvents were of analytical grade and used without further purification. 


\section{Apparatus}

Fourier transform infrared (FT-IR) spectra were obtained using a Nicolet 670 FT-IR spectrometer (USA) and the samples were ground and pressed into $\mathrm{KBr}$ pellets for analysis. The BET surface area was measured by nitrogen adsorption/desorption at $77 \mathrm{~K}$ using a QuadraSorb SI surface area after degassing the samples at $100{ }^{\circ} \mathrm{C}$ for $10 \mathrm{~h}$. Carbon and nitrogen were determined using vario EL III Elemental analyzer (GER). A 721 model UV-Vis spectrophotometer (Shanghai Precision Instruments Co) was used to determine $\mathrm{U}^{\mathrm{VI}}$ as $\mathrm{U}^{\mathrm{VI}}$-arsenazo III complex. A PHS-25 model digital pH meter (Shanghai Precision Instruments Co.) was used to determine the $\mathrm{pH}$ values of solutions.

Synthesis of ion-imprinted and non-imprinted and crosslinked HQ-type chitosan resins

The quinoline-8-ol type chitosan was synthesized in a similar manner to the previous work. ${ }^{18,20}$ Briefly, a mass of $5 \mathrm{~g}$ of chitosan particles was dissolved in $500 \mathrm{~mL}$ of $15 \% \mathrm{v} \mathrm{v}^{-1}$ acetic acid solution with stirring. Then, a mass of $10 \mathrm{~g}$ of 5-chloromethyl-8-quinolinol hydrochloride and $30 \mathrm{~mL}$ of dry triethylamine were added. The reaction mixture was refluxed at $75^{\circ} \mathrm{C}$ for $36 \mathrm{~h}$. After the reaction, the HQ-type chitosan resin was filtered and washed each three times with ethanol and ether to remove unreacted 5-chloromethyl-8-quinolinol. The IR adsorption frequency assignment to the THQ-type chitosan was $1595 \mathrm{~cm}^{-1}$ (corresponding to $\mathrm{C}=\mathrm{N}$ of the quinoline ring), whose frequency depicted the additional bands compared with chitosan itself. The IR spectra of HQ-type chitosan showed $\mathrm{N}-\mathrm{H}$ and $\mathrm{O}-\mathrm{H}$ stretching in $3415 \mathrm{~cm}^{-1}$ (corresponding to $3432 \mathrm{~cm}^{-1}$ of chitosan), which indicated that new bonds between $\mathrm{N}$ and quinoline ring were developed. These bands are due to the ring of quinoline introduced into the chitosan as a base material. Furthermore, the results of elemental analysis (Table 1) confirm the IR spectral data described above, which demonstrate the successful preparation of THQ-type chitosan.

About $2 \mathrm{~g}$ of HQ-type chitosan resin was dissolved in $100 \mathrm{~mL}$ of $5 \% \mathrm{v} \mathrm{v}^{-1}$ acetic acid and $4 \mathrm{~g}$ of $\mathrm{UO}_{2}\left(\mathrm{NO}_{3}\right)_{3} \cdot 6 \mathrm{H}_{2} \mathrm{O}$ was added slowly with stirring at room temperature. The solution above described was poured into the dispersion medium, which was composed of toluene, petroleum ether $\left(1: 1, \mathrm{v} \mathrm{v}^{-1}\right)$ and an emulsifier Tween- $80^{\circledR}$. The dispersion medium was stirred with a mechanical stirrer at $1000 \mathrm{rpm}$ at room temperature. Then, $30 \mathrm{~min}$ later, $2 \mathrm{~mL}$ epichlorohydrin was added to the reaction mixture. The reaction mixture was stirred for further $5 \mathrm{~h}$. After the
Table 1. Elemental analysis and properties of chitosan resins

\begin{tabular}{|c|c|c|c|c|c|}
\hline & \multicolumn{2}{|c|}{$\begin{array}{c}\text { Elemental } \\
\text { analysis }(\%)\end{array}$} & \multirow[t]{2}{*}{$\begin{array}{c}\text { Surface } \\
\text { area / } \\
\left(\mathrm{m}^{2} \mathrm{~g}^{-1}\right)\end{array}$} & \multirow[t]{2}{*}{$\begin{array}{c}\text { Pore } \\
\text { diameter / } \\
(\mathrm{nm})\end{array}$} & \multirow[t]{2}{*}{$\begin{array}{c}\text { Bulk } \\
\text { density } / \\
\left(\mathrm{g} \mathrm{cm}^{-3}\right)\end{array}$} \\
\hline & $\mathrm{C}$ & $\mathrm{N}$ & & & \\
\hline Chitosan & $\begin{array}{c}44.63^{\mathrm{a}} \\
(44.72)^{\mathrm{b}}\end{array}$ & $\begin{array}{c}8.71^{\mathrm{a}} \\
(8.70)^{\mathrm{b}}\end{array}$ & - & - & - \\
\hline HQ-type chitosan & $\begin{array}{c}58.62^{\mathrm{a}} \\
(58.53)^{\mathrm{b}}\end{array}$ & $\begin{array}{c}8.64^{\mathrm{a}} \\
(8.54)^{\mathrm{b}}\end{array}$ & - & - & - \\
\hline IIC-HQ-CTS & - & - & 583 & 5.16 & 0.64 \\
\hline NIC-HQ-CTS & - & - & 532 & 4.99 & 0.71 \\
\hline
\end{tabular}

${ }^{\mathrm{a}}$ Found value; ${ }^{\mathrm{b}} \mathrm{Calculated}$ value.

reaction, the ion-imprinted cross-linked HQ-type chitosan resin (IIC-HQ-CTS) was collected by filtering and washed consecutively with ether and acetone three times. The imprint ion, $\mathrm{UO}_{2}{ }^{2+}$ was leached out from $2 \mathrm{~g}$ of chitosan resin obtained above by stirring with $100 \mathrm{~mL}$ of $5.0 \mathrm{~mol} \mathrm{~L}^{-1}$ $\mathrm{HCl}$ for $6 \mathrm{~h}$. The obtained product was then dried in an oven at $40{ }^{\circ} \mathrm{C}$ for $24 \mathrm{~h}$.

The synthesis of the corresponding non-imprinted cross-linked HQ-type chitosan resin (NIC-HQ-CTS) was carried out using the same procedures as those described above, except imprinted ion. These NIC-HQ-CTS resins were also subjected to the same pretreatment as that of IIC-HQ-CTS.

\section{Procedure of batch "static" method}

A sample solution containing 2-200 $\mu$ g of uranium (VI) in a volume of $10-1000 \mathrm{~mL}$ was taken and its $\mathrm{pH}$ was adjusted to $c a$. 5.0 by adding sodium acetate-acetic acid buffer. The resins $(0.1 \mathrm{~g})$ were added to the above solution and stirred for $1 \mathrm{~h}$ at room temperature. Then, they were filtered before the pre-concentrated metal ions were eluted with $10 \mathrm{~mL}$ of $1.0 \mathrm{~mol} \mathrm{~L}^{-1} \mathrm{HCl}$ for $10 \mathrm{~min}$ and determined spectrophotometrically using Arsenazo III method. ${ }^{21}$ The eluent was taken and $5 \mathrm{~mL}$ of $1: 1 \mathrm{HCl}$ and $1.0 \mathrm{~mL}$ $0.1 \% \mathrm{~m} \mathrm{v}^{-1}$ arsenazo III were added and diluted to $25 \mathrm{~mL}$. The absorbance of uranium (VI)-arsenazo III complex was measured at $656 \mathrm{~nm}$.

\section{Procedure of column "dynamic" method}

Around $0.1 \mathrm{~g}$ of resins was wetted in $5 \mathrm{~mL}$ ethanol and $5 \mathrm{~mL}$ deionized water was added. The wetted resin was packed into the glass column (size: $4.0 \mathrm{~mm}$ diameter and $10 \mathrm{~cm}$ length) and washed three times with $50 \mathrm{~mL}$ deionized water. A volume of $500 \mathrm{~mL}$ of sample solution of uranium (VI) was taken and the $\mathrm{pH}$ adjusted to 5.0 and passed through the above column at a flow rate 
of $2.0 \mathrm{~mL} \mathrm{~min}^{-1}$ using a peristaltic pump. The metal ions were eluted with $10 \mathrm{~mL}$ of $1.0 \mathrm{~mol} \mathrm{~L}^{-1} \mathrm{HCl}$ and determined spectrophotometrically using the method as mentioned above.

Procedure for the analysis of standard, soil and sediment samples

About $0.10-0.50 \mathrm{~g}$ of sample was treated with $5 \mathrm{~mL}$ concentrated $\mathrm{HF}$ and $1.0 \mathrm{~mL}$ concentrated $\mathrm{HNO}_{3}$ at $160^{\circ} \mathrm{C}$ on sand bath till the mixture became dry. The mixture was cooled and treated with $10 \mathrm{~mL}$ nitrohydrochloric acid (aqua regia) on sand bath till the mixture was dry. The residue was then cooled, dissolved in $50 \mathrm{~mL}$ of deionized water. The amount of uranium in the sample was determined using the procedure of column "dynamic" method.

\section{Results and Discussion}

\section{Properties of chitosan resins}

The IIC-HQ-CTS and NIC-HQ-CTS resins were successfully prepared applying the procedure described in experimental section. As listed in Table 1, the Brunauer-Emmett-Teller (BET) analyses indicate that the largest surface areas for IIC-HQ-CTS and NIC-HQCTS are 583 and $532 \mathrm{~m}^{2} \mathrm{~g}^{-1}$, respectively. The obtained resins have large specific surface areas and low bulk density which demonstrate the mesoporous structures of these resins.

\section{Influence of solution pH on uranium (VI) extraction}

The influence of solution $\mathrm{pH}$ on uranium (VI) extraction was investigated by the batch "static" method. A series of solution containing $100 \mu \mathrm{g}$ of uranium (VI) ion in a volume of $1000 \mathrm{~mL}$ was taken and the $\mathrm{pH}$ of these solutions was adjusted between 3.0 and 8.0. The results indicated that the pre-concentration of uranium (VI) is constant and maximum in the $\mathrm{pH}$ range 4.5-7.0 (Figure 2). At $\mathrm{pH} \leq 4.5$, the $=\mathrm{N}-$ and $-\mathrm{OH}$ functionalities in quinoline- 8 -ol which may participate in chelation were protonated leading to the depression in the percent pre-concentration due to the electrostatic repulsion with the positively charged uranyl species. ${ }^{22} \mathrm{At} \mathrm{pH}>5$, various species of uranium (VI) were detected which are not responsible for uranium uptake by resins. ${ }^{23}$ Hence the $\mathrm{pH}$ was adjusted to $5.0 \mathrm{in}$ all subsequent studies. Furthermore, as seen in Figure 2, the percent preconcentration of IIC-HQ-CTS is slightly higher than that of NIC-HQ-CTS in all $\mathrm{pH}$ conditions, which can be attributed to the imprinting effect.

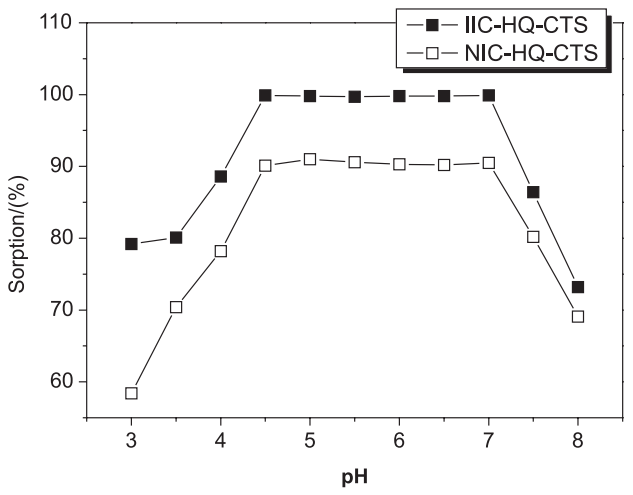

Figure 2. Effect of $\mathrm{pH}$ on the pre-concentration of uranium(VI) using IIC-HQ-CTS or NIC-HQ-CTS resin (100 $\mu \mathrm{g}$ of U UI , batch "static"method, $1000 \mathrm{~mL}$ aqueous solution).

\section{Retention or sorption capacity for uranium (VI)}

The retention capacities of the chitosan resins were investigated within a wide range of initial metal ion concentration (10-200 $\left.\mathrm{mg} \mathrm{L}^{-1}\right)$. As it can be seen in Figure 3, the quantity of uranium (VI) retained augment with increasing amount of uranium (VI) taken initially and reaches a plateau in the range $180-200 \mathrm{mg} \mathrm{L}^{-1}$. Moreover, compared to the non-imprinted resin, the ion-imprinted HQ-type chitosan resins offer higher retention capacities. The maximum retention capacities of IIC-HQ-CTS and NIC-HQ-CTS resin were found to be 218 and $136 \mathrm{mg} \mathrm{g}^{-1}$, respectively. Again, as in the case of above section, it can be explained by an imprinting effect. More significantly, these results indicated that the improvement of uranium (VI) extraction is achievable by an imprinting procedure for the functionalized chitosan. Furthermore, the retention capacities of ion-imprinted or non-imprinted HQ-type chitosan resins in the present study are higher than other quinoline-8-ol impregnated ${ }^{16}$ and anchored ${ }^{17}$ polystyrene divinylbenzene resins, suggesting the advantages of chitosan over other synthetic base materials.

\section{Kinetics of uranium (VI) extraction}

To determine the rate of loading of $\mathrm{U}^{\mathrm{VI}}$ on the resin, batch "static" experiments were carried out in $\mathrm{pH} 5.0$ solutions using $0.1 \mathrm{~g}$ resins stirred with $250 \mathrm{~mL}$ of metal ion solution. At predetermined intervals, aliquots of $5 \mathrm{~mL}$ solution were collected for analysis. The loading halftime $\left(t_{1 / 2}\right)$ is defined as the time in which resins attain 50\% saturation with $\mathrm{U}^{\mathrm{VI}}$. From the kinetics of IIC-HQ-CTS and NIC-HQ-CTS, it was observed that an equilibrium time of about 5 min was required for the maximum sorption. The loading half-times $\left(t_{1 / 2}\right)$ of the chitosan resins were both about $1.5 \mathrm{~min}$. The faster adsorption rate of $\mathrm{U}^{\mathrm{VI}}$ on the IIC-HQ-CTS and NIC-HQ-CTS probably suggests a 


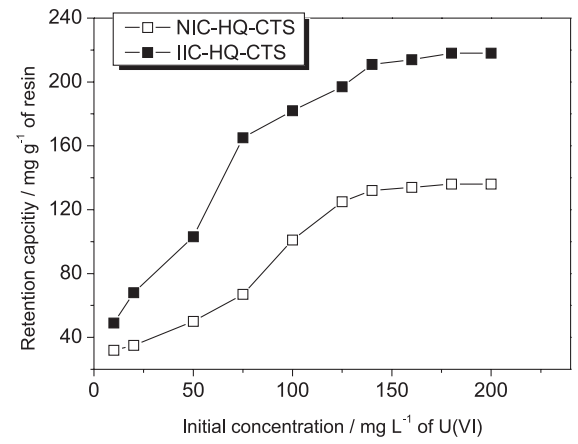

Figure 3. Retention capacities of IIC-HQ-CTS and NIC-HQ-CTS resin (pH 5.0, $500 \mathrm{~mL}$ aqueous solution).

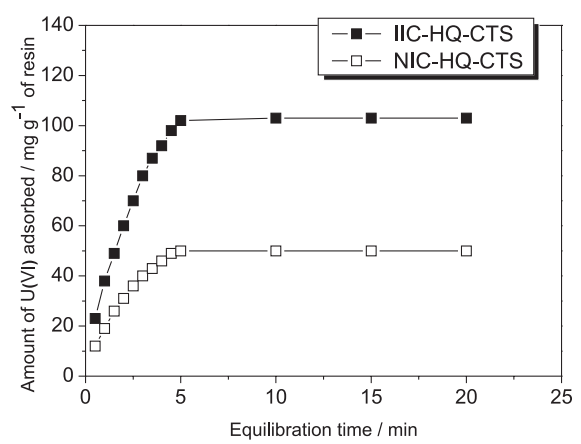

Figure 4. Effect of equilibration time on the adsorption of uranium (VI) (pH 5.0, uranium (VI) concentration: $50 \mathrm{mg} \mathrm{L}^{-1}, 250 \mathrm{~mL}$ ).

better accessibility of the metal ions to the chelating sites in the chitosan, which is due to the good hydrophilicity of chitosan itself ..$^{24}$

\section{Optimization of experimental variables in column methods}

In order to optimize the parameters that influence the enrichment of uranium (VI) from dilute aqueous solution, the column "dynamic" method was carried out in view of the quantitative recovery. A series of solution containing $100 \mu \mathrm{g} \mathrm{U}^{\mathrm{VI}}$ ion in $500 \mathrm{~mL}$ were taken and the $\mathrm{pH}$ of these solutions was adjusted to $c a$. 5.0 and the recommended column procedure was followed. The results obtained using IIC-HQ-CTS and NIC-HQ-CTS resins under different eluents, eluent concentrations, eluent volumes and eluent flow rates are summarized in Table 2. As it can be seen in Table 2, hydrochloric acid alone promotes quantitative elution of previously pre-concentrated uranium (VI) for IIC-HQ-CTS resin in a concentration of $0.5 \mathrm{~mol} \mathrm{~L}^{-1}$. Hence, $1 \mathrm{~mol} \mathrm{~L}^{-1} \mathrm{HCl}$ was employed in subsequent studies in order to ensure complete elution even at higher amount of metal ion. Also seen from Table 2, an eluent volume as low as $8 \mathrm{~mL}$ was enough to offer quantitative recovery using IIC-HQ-CTS resin. Therefore, $10 \mathrm{~mL}$ eluent volume was employed in subsequent studies. The optimum eluent flow rates obtained ranged from 1.0 to $3.0 \mathrm{~mL} \mathrm{~min}^{-1}$, and an increase in flow rate resulted in a decrease in extraction due to insufficient contact time between the resin and the metal ion solution. A flow rate of $2 \mathrm{~mL} \mathrm{~min}^{-1}$ was employed in subsequent studies so as to ensure quantitative recovery even at higher amount of metal ion and avoid extended analysis times. Once again, imprinting effect was evident in all the instances. Under these optimum conditions, quantitative pre-concentration and elution of uranium (VI) was obtained for aqueous phase volumes varying in the range $10-500 \mathrm{~mL}$, which shows that enrichment or preconcentration factor was $c a .50$.

Table 2. Effect of various parameters on the percent of extraction of uranium with IIC-HQ-CTS and NIC-HQ-CTS by column method

\begin{tabular}{|c|c|c|}
\hline \multirow{2}{*}{ Parameter } & \multicolumn{2}{|c|}{ Extraction $(\%)$} \\
\hline & IIC-HQ-CTS & NIC-HQ-CTS \\
\hline \multicolumn{3}{|l|}{ Nature of eluent } \\
\hline $1 \mathrm{~mol} \mathrm{~L}^{-1} \mathrm{HCl}$ & $>99$ & $94.5 \pm 0.2$ \\
\hline $1 \mathrm{~mol} \mathrm{~L}^{-1} \mathrm{HNO}_{3}$ & $87.6 \pm 0.5$ & $80.3 \pm 0.2$ \\
\hline $0.5 \mathrm{~mol} \mathrm{~L}^{-1} \mathrm{H}_{2} \mathrm{SO}_{4}$ & $90.2 \pm 0.3$ & $86.4 \pm 0.4$ \\
\hline \multicolumn{3}{|c|}{ Eluent $(\mathrm{HCl})$ concentration $\left(\mathrm{mol} \mathrm{L}^{-1}\right)$} \\
\hline 0.2 & $92.1 \pm 0.6$ & $72.6 \pm 0.5$ \\
\hline 0.5 & $>99$ & $92.4 \pm 0.3$ \\
\hline 1.0 & $>99$ & $94.5 \pm 0.2$ \\
\hline \multicolumn{3}{|l|}{ Eluent volume $(\mathrm{mL})$} \\
\hline 2 & $82.5 \pm 0.4$ & $62.4 \pm 0.7$ \\
\hline 5 & $97.1 \pm 0.6$ & $79.5 \pm 0.5$ \\
\hline 8 & $>99$ & $87.4 \pm 0.3$ \\
\hline 10 & $>99$ & $94.5 \pm 0.2$ \\
\hline \multicolumn{3}{|l|}{ Eluent flow rate $\left(\mathrm{mL} \mathrm{min}{ }^{-1}\right)$} \\
\hline 1 & $>99$ & $94.5 \pm 0.2$ \\
\hline 2 & $>99$ & $94.5 \pm 0.2$ \\
\hline 3 & $>99$ & $92.5 \pm 0.2$ \\
\hline 4 & $93.5 \pm 0.3$ & $81.6 \pm 0.3$ \\
\hline
\end{tabular}

Resins stability and reusability

The regeneration of resins may be important for keeping the process costs down and offering the possibility of recovering the metal ion extracted from the solution. For this purpose, it is desirable to desorb the sorbed metal ions and to regenerate the resin for another cycle of application. ${ }^{10}$ For chitosan resins solubilizing in acid aqueous solution, cross-linking opens the possibility of developing stability and reproducibility. ${ }^{25}$ Here, to evaluate resin stability and res-usability, the uranium (VI) was loaded and eluted several 
times. The retention capacities of the IIC-HQ-CTS and NIC-HQ-CTS resins decreased less than $2 \%$ over 20 loadingelution cycles, indicating the possible reuse of resins for practical applications. Furthermore, it was observed that the retention capacities of the resins under ambient conditions remained practically unchanged after storing for 60 days.

\section{Breakthrough studies}

Breakthrough capacity is significant and applied in SPE applications as it offers actual working capacity of the resin in the column. The pre-concentrating abilities of the obtained resins were assessed by using a series of sample volumes containing $10 \mu \mathrm{g} \mathrm{mL}^{-1}$ uranium (VI) ion passed through the preconditioned column at the optimum conditions described above. Salient breakthrough curves for uranium (VI) are shown in Figure 5. As seen, breakthrough capacities of the IIC-HQ-CTS and NIC-HQ-CTS resins for uranium (VI) were 62,400 and $44,800 \mu \mathrm{g} \mathrm{mL}^{-1}$, respectively. Considering the relation of breakthrough points of these two chitosan resins, it is suggested that an appealing feature of greater affinity for uranium (VI) was attainable by the ion imprinting.

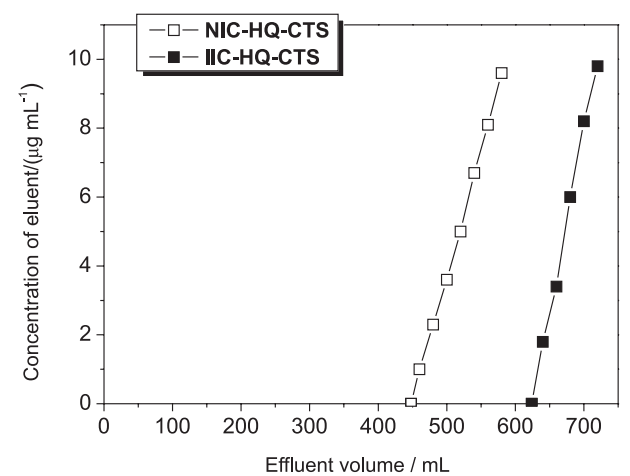

Figure 5. Breakthrough curves for $\mathrm{U}^{\mathrm{VI}}$ on the IIC-HQ-CTS and NIC-HQ-CTS resins.

\section{Statistical and calibration parameters for column method}

The calibration parameters for the enrichment of uranium (VI) in the proposed IIC-HQ-CTS method using the column technique were investigated under the optimum conditions described above. The calibration curve was linear over the concentration range 5-100 $\mu \mathrm{g} \mathrm{L}^{-1}$ of uranium. The limit of detection (LOD) defined as the metal ion concentration giving a signal equal to three times the standard deviation of the blank signal divided by the slope of the analytical calibration curve was found to be $2.0 \mu \mathrm{g} \mathrm{L}^{-1}$. The precision of the proposed method was investigated using a $20 \mu \mathrm{g}$ metal ion present in $1.0 \mathrm{~L}$ of solution, which gave a mean absorbance of 0.039 and expressed as RSD: $1.96 \%$. The linear equation with regression is:

$$
\mathrm{A}=0.00206 \mathrm{C}-0.0021
$$

$$
\mathrm{R}^{2}=0.9996
$$

where $A$ is the peak height absorbance, $C$ is the concentration in $\mu \mathrm{g} \mathrm{\textrm {L } ^ { - 1 }}$, and $\mathrm{R}$ is the regression coefficient.

\section{Tolerance of electrolytes and diverse ions}

Considering the feasibility of complexes formation between chloride, sulfate, phosphate anions and several metal ions including uranium (VI), the efficiency of the IIC-HQ-CTS resin in binding metal ions must be checked for possible reduction in extraction. Under the conditions of optimum pre-concentration of uranium (VI), the effects of $\mathrm{NaCl}, \mathrm{NaNO}_{3}, \mathrm{Na}_{2} \mathrm{SO}_{4}, \mathrm{CaCl}_{2}, \mathrm{NaSCN}, \mathrm{KCl}, \mathrm{EDTA}$, $\mathrm{NH}_{4} \mathrm{Cl}, \mathrm{Na}_{3} \mathrm{PO}_{4}$, and $\mathrm{Na}_{2} \mathrm{CO}_{3}$ on the IIC-HQ-CTS resin were studied using the recommended column method for $1 \mu \mathrm{g} \mathrm{mL} \mathrm{m}^{-1} \mathrm{U}$ (VI) solution in a volume of $100 \mathrm{~mL}$. The tolerance of electrolytes was summarized in Table 3. Analogously, the effects of several cations (which are likely to co-exist with uranium (VI) in its minerals ores) were also investigated, and the results are summarized in Table 3. Clearly, the high tolerance of electrolytes and diverse ions is due to the specific binding to the uranium (VI) ions in the imprinted resin.

Table 3. Tolerance limits of electrolytes and cations on the

\begin{tabular}{|c|c|c|}
\hline Electrolytes/Cations & Compound & $\begin{array}{l}\text { Tolerance limits / } \\
\left(\mathrm{mg} \mathrm{L}^{-1}\right)\end{array}$ \\
\hline $\mathrm{NaCl}$ & $\mathrm{NaCl}$ & 11,688 \\
\hline $\mathrm{NaNO}_{3}$ & $\mathrm{NaNO}_{3}$ & 16,998 \\
\hline $\mathrm{Na}_{2} \mathrm{SO}_{4}$ & $\mathrm{Na}_{2} \mathrm{SO}_{4}$ & 21,306 \\
\hline $\mathrm{CaCl}_{2}$ & $\mathrm{CaCl}_{2}$ & 11,098 \\
\hline $\mathrm{NaSCN}$ & $\mathrm{NaSCN}$ & 8,107 \\
\hline $\mathrm{KCl}$ & $\mathrm{KCl}$ & 14,910 \\
\hline EDTA & EDTA & 29,225 \\
\hline $\mathrm{NH}_{4} \mathrm{Cl}$ & $\mathrm{NH}_{4} \mathrm{Cl}$ & 8,024 \\
\hline $\mathrm{Na}_{3} \mathrm{PO}_{4}$ & $\mathrm{Na}_{3} \mathrm{PO}_{4}$ & 4,918 \\
\hline $\mathrm{Na}_{2} \mathrm{CO}_{3}$ & $\mathrm{Na}_{2} \mathrm{CO}_{3}$ & 5,299 \\
\hline $\mathrm{Fe}(\mathrm{III})$ & $\mathrm{FeCl}_{3}$ & 15 \\
\hline $\mathrm{Co}(\mathrm{II})$ & $\mathrm{CoSO}_{4} \cdot 7 \mathrm{H}_{2} \mathrm{O}$ & 60 \\
\hline $\mathrm{Ni}(\mathrm{II})$ & $\mathrm{NiCl}_{2} \cdot \mathrm{H}_{2} \mathrm{O}$ & 50 \\
\hline Al(III) & $\mathrm{Al}\left(\mathrm{No}_{3}\right)_{3} \cdot 9 \mathrm{H}_{2} \mathrm{O}$ & 75 \\
\hline $\mathrm{Cu}(\mathrm{II})$ & $\mathrm{CuSO}_{4} \cdot 5 \mathrm{H}_{2} \mathrm{O}$ & 50 \\
\hline $\operatorname{Mn}(\mathrm{II})$ & $\mathrm{MnSO}_{4} \cdot \mathrm{H}_{2} \mathrm{O}$ & 75 \\
\hline $\mathrm{Pb}(\mathrm{II})$ & $\mathrm{Pb}\left(\mathrm{NO}_{3}\right)_{2}$ & 60 \\
\hline $\mathrm{Zn}(\mathrm{II})$ & $\mathrm{ZnSO}_{4} \cdot 7 \mathrm{H}_{2} \mathrm{O}$ & 70 \\
\hline $\operatorname{Th}(\mathrm{IV})$ & $\mathrm{Th}\left(\mathrm{NO}_{3}\right)_{4} \cdot 6 \mathrm{H}_{2} \mathrm{O}$ & 40 \\
\hline
\end{tabular}
pre-concentration of $\mathrm{U}^{\mathrm{VI}}$ on the IIC-HQ-CTS resin 


\section{Analysis of soil samples and standard uranium ore samples}

To verify applications and validations of the proposed method, one standard reference material, soil collected from farmland and sediment collected from the Gongxi River were subjected to dissolution, pre-concentration and determination. The results obtained for the standard reference material are shown in Table 4, and those for the soil sample and the sediment sample are shown in Table 5. The results obtained are in good agreement with the certified values and the recoveries of spiked uranium were quantitative. Thus, these results indicated that the SPE pre-concentration method with IIC-HQ-CTS resin developed in the present work is accurate, simple and low cost for analyzing ore, soil and sediment samples containing traces of uranium.

Table 4. Analysis of uranium ore standard reference material (GBW04108)

\begin{tabular}{lcccc}
\hline No. & $\begin{array}{c}\text { Uranium } \\
\text { added / } \\
\left(\mu \mathrm{g} \mathrm{g}^{-1}\right)\end{array}$ & $\begin{array}{c}\text { Uranium found } /\left(\mu \mathrm{g} \mathrm{g}^{-1}\right) \\
\text { method }^{\mathrm{a}}\end{array}$ & Certified $^{\mathrm{b}}$ & $\begin{array}{c}\text { Recovery / } \\
(\%)\end{array}$ \\
\hline 1 & None & $82 \pm 0.50$ & 79 & - \\
2 & 60 & $140 \pm 0.30$ & & 101.7 \\
3 & 120 & $202 \pm 0.30$ & 102.5 \\
\hline
\end{tabular}

${ }^{a}$ Average and standard deviation from triplicate runs carried out with a single column; ${ }^{\text {b }}$ Certified values reported by Centre of China Reference Materials.

Table 5. Determination of uranium(VI) in soil and sediment samples

\begin{tabular}{|c|c|c|c|c|}
\hline \multirow{2}{*}{ No. } & \multirow{2}{*}{ Description of the sample } & \multicolumn{2}{|c|}{ Uranium $/\left(\mu \mathrm{g} \mathrm{g}^{-1}\right)$} & \multirow{2}{*}{$\begin{array}{c}\text { Recovery } \\
(\%)\end{array}$} \\
\hline & & Added & Found $^{\mathrm{a}}$ & \\
\hline \multirow{3}{*}{1} & \multirow{3}{*}{$\begin{array}{l}\text { Soil sample from farmland } \\
\text { nearby the } 721 \text { Uranium Mines }\end{array}$} & - & $8.65 \pm 0.30$ & \\
\hline & & 8.0 & $16.8 \pm 0.20$ & 101.9 \\
\hline & & 16.0 & $24.85 \pm 0.25$ & 101.3 \\
\hline \multirow{3}{*}{2} & \multirow{3}{*}{$\begin{array}{l}\text { Sediment from Gongxi River } \\
\text { nearby the } 721 \text { Uranium Mines }\end{array}$} & - & $4.40 \pm 0.15$ & \\
\hline & & 4 & $8.46 \pm 0.25$ & 101.5 \\
\hline & & 8 & $12.44 \pm 0.20$ & 100.5 \\
\hline
\end{tabular}

${ }^{a}$ Average and standard deviation from triplicate run carried out with a single column.

\section{Conclusions}

Solid phase extraction with an ion-imprinted cross-linked HQ-type chitosan resin provides an effective pre-concentration of uranium (VI). In all cases, a significant imprinting effect was noticed when comparing the efficiency of extractions of uranium (VI) with ion-imprinted and corresponding nonimprinted chitosan resins. The ion-imprinted cross-linked chitosan resins, IIC-HQ-CTS gave higher retention capacity ( $218 \mathrm{mg} \mathrm{g}^{-1}$ ), quantitative recoveries in the $\mathrm{pH}$ range 4.5 to 7.0 , and elevated tolerance to electrolytes and diverse ions. The
IIC-HQ-CTS resins can be reused as they are unaffected even after 20 cycles demonstrating a high mechanical and chemical strength. The proposed column method offers low detection limits and is more precise (as RSD is $1.96 \%$ ). Furthermore, the accuracy of the developed SPE method was verified by analyzing one uranium ore standard reference material for uranium (VI), and the proposed SPE method was applied to the determination of uranium in soil and sediment samples. Hence, the SPE preconcentration method with an ion-imprinted crosslinked HQ-type chitosan resin provides a simple, accurate and low cost procedure for the determination of trace amounts of uranium(VI) in soil, ore and sediment samples.

\section{Acknowledgments}

This work was financially supported by National Natural Science Foundation of China (Grant No. 20862001), National Defense Basic Research Foundation of China (Grant No. A3420060146), Provincial Natural Science Foundation of Jiangxi (Grant No. 2008GQH0051) and Sci. \& Tech. Project of Jiangxi Provincial Department of Education (Grant No. GJJ09528).

\section{References}

1. Milgram, S.; Carrière, M.; Thiebault, C.; Malaval, L.; Gouget, B.; Toxicology 2008, 250, 62.

2. WHO: Guidelines for Drinking Water Quality, $2^{\text {nd }}$ ed., Addendum to vol. 2, Health Criteria and Other Supporting Information, WHO/EOS/98-1, Geneva, 1998.

3. Elnaggar, I. M.; Shabana, E. I.; Eldessouky, M. I.; Talanta 1992 , 396,53

4. Kannan, S.; Deb, S. B.; Gamare, J. S.; Drew, M. G. B.; Polyhedron 2008, 272, 557.

5. Rao, T. P.; Preetha, C. R.; Sep. Purif. Rev. 2003, 32, 1.

6. Miura, T.; Morimoto, T.; Hayano, K.; Kishimoto, T.; Bunseki Kagaku 2000, 49, 245.

7. Perma, L.; Betti, M.; Moreno, J. M. B.; Fuoco, R.; J. Anal. At. Spectrom. 2001, 16, 26.

8. Carter, H. E.; Warwick, P.; Cobb, J.; Longworth, G.; Analyst 1999, 124, 271.

9. Preetha, C. R.; Rao, T. P.; J. Radioanal. Nucl. Chem. 2006, 267, 265.

10. Crini, G.; Prog. Polym. Sci. 2005, 30, 38.

11. Inoue, T. T. K.; Baba, Y.; Chitosan: A Versatile Biopolymer for Separation, Purification and Concentration of Metal Ions, CRC Press: New York, 2007.

12. Oshita, K.; Oshima, M.; Gao,Y.; Lee, K. H.; Motomizu, S.; Anal. Chim. Acta 2003, 480, 239.

13. Oshita, K.; Seo, K.; Sabarudin, A.; Oshima, M.; Takayanagi, T.; Motomizu, S.; Anal. Bioanal. Chem. 2008, 390, 1927. 
14. Yamakawa, S.; Oshita, K.; Sabarudin, A.; Oshima, M.; Motomizu, S.; Bunseki Kagaku 2004, 53, 1039.

15. Sabarudin, A.; Oshima, M.; Takayanagi, T.; Hakima, L.; Gao, Y. H.; Motomizu, S.; Anal. Chim. Acta 2007, 581, 214.

16. Gladis, J. M.; Rao, T. P.; Anal. Bioanal. Chem. 2002, 373, 867.

17. Praveen, R. S.; Metilda, P.; Daniel, S.; Rao, T. P.; Talanta 2005, 67, 960.

18. Inoue, K.; Hirakawa, Y. H.; Ishikawa, Y.; Sep. Sci. Technol. 1996, 312, 273.

19. Metilda, P.; Gladis, J. M.; Rao, T. P.; Anal. Chim. Acta 2004, 512,63 .
20. Lang, H. Y.; Zhang, X. J.; Wei, Y. F.; Chem. J. Chinese Universities 2004, 25, 770.

21. Song, J. R.; The Chemical Analysis of Uranium Ore; Atomic Energy Press: Beijing, 2006.

22. Atia, A. A.; Hydrometallurgy 2005, 80, 13.

23. Brynda, M.; Wesolowski, T. A.; Wojcichowski, K.; J. Phys. Chem. A 2004, 108, 5091.

24. Gao,Y.; Oshita, K.; Lee, K. H.; Oshima, M.; Motomizu, S.; Analyst 2002, 127, 1713.

25. Wan Ngah, W. S.; Endud, C. S.; Mayanar, R.; React. Funct. Polym. 2002, 50, 181. 